
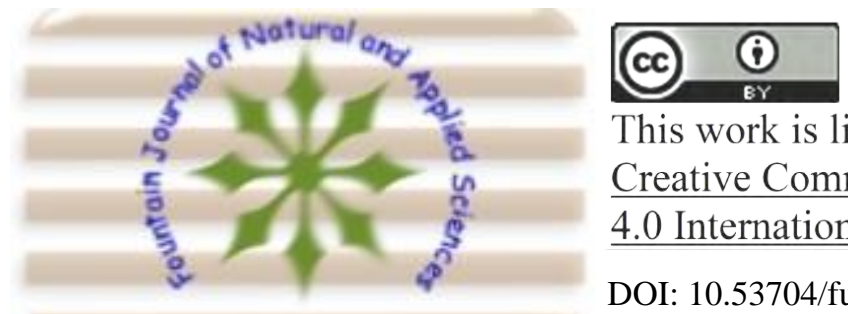

This work is licensed under Creative Commons Attribution 4.0 International License.

DOI: $10.53704 /$ fujnas.v9i2.343

A publication of College of Natural and Applied Sciences, Fountain University, Osogbo, Nigeria. Journal homepage: www.fountainjournals.com

ISSN: 2354-337X(Online),2350-1863(Print)

\title{
Antioxidant Parameters, Lipid Profiles and Performance Studies of Broiler Birds Fed Graded Level Taurine-Supplemented Diets
}

\author{
* ${ }^{1}$ Ogunbode, S. M., ${ }^{1}$ Oladimeji, R. A., ${ }^{1}$ Salaudeen, Q. O., ${ }^{1}$ Bello, R. A. and ${ }^{2}$ Majolagbe, H. O. \\ 1Department of Chemical Sciences, Nutritional Biochemistry Laboratory Unit, Fountain University, Osogbo, Nigeria. \\ ${ }^{2}$ Adeniran Ogunsanya College of Education, Otto, Ijanikin, Nigeria.
}

\begin{abstract}
The research was targeted towards monitoring the activities of antioxidant enzymes, levels of non-enzymic antioxidants, lipid profiles and performance activities of broiler birds fed taurine-supplemented diets. One hundred and eighty 1-day-old unsexed arbor acre strain broiler birds were randomly distributed into five dietary treatments, six replicates per treatment and six birds per replicate. Treatments 1 to 5 contained $0 \%$, $0.002 \%, 0.004 \%, 0.006 \%$ and $0.008 \%$ taurine supplements respectively as add-over. Treatment 1 served as the control diet. The birds were grouped and brooded for a week and the experiment lasted for six weeks. The birds were sacrificed and the liver, kidneys and serum were collected. The activities of catalase and myeloperoxidase, concentrations of reduced glutathione and nitric oxide as well as the serum lipid profiles were monitored. Liver catalase activities was highest for birds placed on 0.006 and $0.008 \%$ taurine-supplemented diets as compared with those on $0 \%$ taurine-supplemented diet. The trend was similar for the kidney reduced glutathione concentration. Liver nitric oxide concentrations and kidney myeloperoxidase activities were significantly higher $(\mathrm{p}<0.05)$ for birds placed on $0.004 \%, 0.006 \%$ and $0.008 \%$ taurine-supplemented diets as compared to birds placed on the control diets. High density lipoprotein was highest for birds on a $0.008 \%$ diet and lowest for birds on the control diet. The best feed conversion ratio was obtained for birds placed on $0.008 \%$ taurine-supplemented diet. Taurinesupplemented diets at between 0.002 and $0.008 \%$ favoured birds' antioxidant defense mechanisms, had no deleterious effect on lipid profile, and equally improved the performance characteristics of broiler birds.
\end{abstract}

Keywords: Taurine, catalase, high density lipoprotein, carcass measures, feed conversion ratio

\section{Introduction}

Taurine, a sulphur-containing derived amino acid is synthesized from methionine and cysteine metabolism (Tufft \& Jensen, 1992). It protects the cells of the body against oxidative stress (Avgerinos et al., 2018; Abplanalp et al., 2019; Seidel et al., 2019; Wu et al., 2019). Taurine has the ability to maintain the integrity of the electron transport chain of the mitochondria, hence could serve as an antioxidant defense mechanism (Surai et al., 2017). It is neither an energy source nor a source of protein but notably assists in bile acid binding, fat

*Corresponding author: 2348038278441 Email address: oyewolar@gmail.com 
digestion and consequently fat absorption (Reshetnyak, 2013; Huang et al., 2014a).

Broiler birds fed with taurine supplemented diets has the ability to improve the health status of the consumers, because it is a nutrient-rich white meat (Huang et al., 2014a). Taurine supplementation in poultry diets has also been proven to improve birds' feed conversion ratio (Begley et al., 2005). Taurine deficiency had earlier been characterized by depressed growth, low survival, increased susceptibility to diseases, increased serum and liver cholesterol and triglycerides as well as impaired growth and development ((El-Sayed, 2014).

The main target of this research is to investigate the efficacy of graded level taurine-supplemented diets at varying concentrations $(0.002-0.008 \%)$ on enzymic and non-enzymic antioxidants, serum lipid profiles and performance indices of broiler birds.

\section{Materials and Methods \\ Chemicals and Reagents}

Kits used for enzyme activities were products of Randox Laboratories, County Antrim, UK. Packed synthesized taurine supplement $(500 \mathrm{~g})$ with pharmacy number 7040, 3109AA used for the research was manufactured by Now Food Essential Products, Schiedam Netherlands. Reagents for other analyses like proximate analysis were of analytical grades and were prepared in the institution laboratory (Fountain University, Osogbo, Nigeria).

\section{Experimental Design and Birds' Management}

One-day-old unsexed broiler birds (180) purchased from Zartech farm, Ibadan, Oyo State, Nigeria were used for the research. Pens were cleaned, electrified and disinfected prior to the arrival of the birds. Five dietary treatments, six replicates and six birds per replicate were arranged in a completely randomized design. Treatment one (T1 - 0\% taurine supplement) served as the control group, Treatments 2, 3, 4 and 5 contained birds fed with the supplement as add-over at 0.002, 0.004, 0.006 , and $0.008 \%$ respectively. The birds were initially immunized against Newcastle disease virus (lasota vaccine) on the $8^{\text {th }}$ day when maternal antibody has subsided (Ogunbode et al., 2013). The lasota vaccine was then repeated on the $28^{\text {th }}$ day. The chicks were equally vaccinated against Infectious Bursal Disease (IBDV) virus on day 10 of age via drinking water and then repeated on the $18^{\text {th }}$ day. Feed and water were given without restriction throughout the study period. Weekly feed intake and weight gain were monitored to allow for calculation of feed to gain ratio. The birds were group-brooded for a week and the experiments lasted for six weeks.

\section{Collection of Blood, Other Tissues and Carcass Evaluation}

At the end of the experimental period, the birds were starved overnight to empty the crop. Blood samples were drawn via the wing web of three birds per replicate, picked randomly as a representative of each group, then later humanely sacrificed in a $\mathrm{CO}_{2}$ chamber following strictly the rules guiding the handling of animals as outlined by Fountain University guidelines for handling of experimental animals. The birds were scalded in hot water, defeathered and dissected. Tissues of interest were then collected, blotted with tissue paper, and a known weight $(0.5 \mathrm{~g})$ were dispensed in $0.45 \mathrm{ml}$ of ice-cold normal saline. The tissues were homogenized, centrifuged, decanted and used within 72 hours to retain the integrity of the enzymes. Collected blood samples were centrifuged using a Gallenkomp Bench Centrifuge 90-1 made in England at 8,000 rpm_for 10 minutes. The serum was then collected using Pasteur pipette, kept frozen and also used within 72 hours.

Cut parts of interest like the breast, thigh, drum stick, back, neck and wings were obtained, and weighed as a percentage of the dressed weight.

\section{Proximate Analysis and Measurement of Biochemical Parameters}

Proximate analysis of feed was carried out in accordance with the method of AOAC (2005). Tissue total protein was determined according to the method of Bradford (1976), reduced glutathione concentration and catalase activity were measured by the method of Ajiboye et al. (2014), nitric oxide concentration by Green et al. (1991), 
myeloperoxidase activity by Tomaz Henrique et al. (2013) and serum lipid profile analysis was according to the method of Folch et al. (1957).

\section{Statistical analysis}

Differences between means were determined using analysis of variance, Duncan's and TukeyKramer's tests were then used for significant differences $(p<0.05)$ between the variables in the study.

\section{Results}

\section{Experimental Feed and Analysis}

Table 1 shows the gross composition $(\mathrm{kg} / 100 \mathrm{~g})$ of the experimental diets as outlined by NRC 1995. The only ingredient (add-over) varied was taurine, which is the main target of the research. The feeds were formulated to be balanced in energy and protein requirement of the birds, taken into cognisance, the basic requirements for micronutrients and mineral needs of the birds too.

Table 2 compared the calculated nutrient and proximate compositions of the experimental diets so as to ensure narrow variations, hence to authenticate the purpose of the research. The analysed crude protein ranged between 18.38 and $22.97 \mathrm{~g} / 100 \mathrm{~g} \mathrm{DM}$, the fibre content ranged between 4.52 and $5.33 \mathrm{~g} / 100 \mathrm{~g} / \mathrm{DM}$. while the nitrogen free extract which is the energy source in the diet ranged between 62.89 and $68.96 \mathrm{~g} / 100 \mathrm{~g}$ DM.

The total protein values (Table 3) of the liver of birds placed on $0.006 \%$ and that of the kidney of birds on $0.004 \%, 0.006 \%$ and $0.008 \%$ taurinesupplemented-diets were significantly increased ( $p<0.05$ ). The liver of the birds on $0.002 \%$ and that of the kidney on $0 \%$ dietary taurine supplement had the least amount $(\mathrm{p}<0.05)$ of total protein values.

\section{Dietary Taurine Supplement and Antioxidant Parameters}

Table 4 shows that the concentration of reduced glutathione (GSH) were similar ( $\mathrm{p}>0.05)$ amongst the birds placed on $0.004,0.006$ and $0.008 \%$ $(3.3375,2.9375$ and 3.5585$)$ dietary supplements respectively. In the same vein, birds placed on $0 \%$ and $0.002 \% \quad(2.0108$ and 2.0205) taurine supplements showed no difference $(\mathrm{p}>0.05)$ in the
GSH levels. Liver nitric oxide concentrations were significantly higher $(\mathrm{p}<0.05)$ for birds placed on 0.004 to $0.008 \%$ taurine supplemented diets as compared to birds placed on the control diets. Liver catalase and myeloperoxidase activities of birds on $0.006 \%$ and $0.008 \%$ dietary taurine supplement were significantly different $(\mathrm{p}<0.05)$ when compared with the activities of both enzymes on other varied taurine concentrations within the column.

Table 5 reveals that the kidney GSH concentration of birds on 0.006 and $0.008 \%$ dietary-taurine-supplement were significant $(p<0.005)$ when compared with the levels in the kidney of the birds on other dietary levels of taurine supplementations. Kidney nitric oxide levels were significantly different $(\mathrm{p}<0.005)$ amongst the dietary treatments, with birds on $0.006 \%$ having the highest amount of the biomolecule. Kidney catalase activities of birds on $0.008 \%$ and that of the myeloperoxidase at 0.004, 0.006 and $0.008 \%$ dietary taurine supplements were significant $(\mathrm{p}<0.05)$ when compared with the kidney enzymes activities of birds on other dietary levels of taurine supplementations for both enzymes (catalase and myeloperoxidase) within the column.

\section{Dietary Taurine Supplement and Lipid Profiles} Serum lipid profiles (Table 6) of the birds fed varying concentrations of graded level taurinesupplemented diets showed that the cholesterol and low density lipoprotein were highest $(\mathrm{p}<0.05)$ for birds on the control diet ( $0 \%$ taurine supplement). Triglycerides and high density lipoprotein (HDL) on the other hand were highest $(p<0.05)$ for birds placed on $0.008 \%$ dietary taurine supplement. HDL was lowest $(\mathrm{p}<0.05)$ for birds placed on the control diet.

\section{Dietary Taurine and Performance Indices}

Table 7 reveals that the thigh of birds placed on $0.004 \%$ taurine-supplemented diet was significantly different $(\mathrm{p}<0.05)$ from every other dietary level of taurine supplementation within the column. The breast of the birds placed on 0.002 to $0.008 \%$ dietary taurine-supplemented diets were similar and significantly higher $(p<0.05)$ than the 
Table 1: Gross composition $(\mathrm{kg} / \mathbf{1 0 0 g})$ of experimental diets

\begin{tabular}{lccc}
\hline Ingredient $(\mathbf{k g})$ & $\begin{array}{c}\text { Experimental phase } \\
\text { Pre-starter }\end{array}$ & Starter & Finisher \\
\hline Taurine supplement & & $0.002-0.008$ & \\
Maize & 44.60 & 51.38 & 56.00 \\
Oil & 0.30 & 0.40 & 2.00 \\
Soybeans meal & 32.30 & 21.29 & 18.00 \\
Water & 10.80 & 11.00 & 9.00 \\
Groundnut cake & 9.00 & 13.00 & 2.00 \\
Lime stone & 1.90 & 1.55 & 11.22 \\
Dicalcium phosphate & 0.33 & 0.41 & 2.00 \\
Methionine & 0.14 & 0.17 & 0.37 \\
Lysine & 0.00 & 0.20 & 0.62 \\
Premix & 0.25 & 0.25 & 0.14 \\
\hline Total & 100 & 100 & 100
\end{tabular}

Table 2: Comparison of the calculated (\%) and analysed (g/100 g DM) nutrient composition of experimental diets

\begin{tabular}{lccc}
\multicolumn{1}{c}{ Ingredient } & Pre-starter & Starter & Finisher \\
\hline Crude protein (C) & 22.57 & 20.12 & 18.05 \\
Crude protein (A) & 22.97 & 20.34 & 18.38 \\
Crude fibre (C) & 5.40 & 4.85 & 4.38 \\
Crude fibre (A) & 5.33 & 4.93 & 4.52 \\
Ether extract (C) & 5.10 & 4.84 & 4.40 \\
Ether extract (A) & 4.99 & 4.72 & 4.21 \\
Ash (C) & 3.74 & 3.74 & 3.74 \\
Ash (A) & 3.82 & 3.72 & 3.93 \\
NFE (C) & 63.19 & 66.45 & 69.43 \\
NFE (A) & 62.89 & 66.29 & 68.96 \\
\hline
\end{tabular}

$\mathrm{C}=$ Calculated, $\mathrm{A}-$ Analysed, $\mathrm{NFE}=$ Nitrogen free extract

Table 3: Liver and Kidney total protein of broiler birds fed graded level taurinesupplemented diets $(\mathrm{g} / \mathrm{L})$

\begin{tabular}{ccc} 
Diets & Liver & Kidney \\
\hline DIET 1 & $11.76 \pm 0.383^{\mathrm{d}}$ & $12.94 \pm 0.26^{\mathrm{c}}$ \\
DIET 2 & $13.66 \pm 0.21^{\mathrm{c}}$ & $13.45 \pm 0.32^{\mathrm{b}}$ \\
DIET 3 & $12.60 \pm 0.36^{\mathrm{cd}}$ & $17.76 \pm 0.46^{\mathrm{a}}$ \\
DIET 4 & $18.96 \pm 0.38^{\mathrm{a}}$ & $18.69 \pm 0.31^{\mathrm{a}}$ \\
DIET 5 & $17.23 \pm 0.32^{\mathrm{b}}$ & $18.61 \pm 0.31^{\mathrm{a}}$ \\
\hline
\end{tabular}

Mean \pm SEM (Standard Error of Mean). Diet $1-0 \%$, Diet $2-0.002 \%$, Diet $3-0.004 \%$, Diet $4-0.006 \%$, Diet $5-0.008 \%$ taurine-supplemented diets respectively.

Means within the same column with different superscripts are significantly different $(p<$ 0.05). 
Table 4: Liver antioxidant parameters of broiler birds fed graded level taurinesupplemented diets

\begin{tabular}{lllll}
\hline & \multicolumn{3}{c}{ LIVER } \\
\cline { 2 - 5 } DIETS & GSH $(\mathrm{mg} / \mathrm{dl})$ & NO $(\mathrm{ppm})$ & CAT $(\mu \mathrm{mol} / \mathrm{min})$ & MPO $(\mu \mathrm{mol} / \mathrm{min})$ \\
\hline DIET 1 & $2.01 \pm 0.22^{\mathrm{b}}$ & $0.56 \pm 0.05^{\mathrm{b}}$ & $34.06 \pm 0.44^{\mathrm{c}}$ & $12.93 \pm 0.58^{\mathrm{bc}}$ \\
DIET 2 & $2.02 \pm 0.18^{\mathrm{b}}$ & $0.56 \pm 0.02^{\mathrm{b}}$ & $27.92 \pm 0.29^{\mathrm{d}}$ & $12.03 \pm 0.36^{\mathrm{c}}$ \\
DIET 3 & $3.34 \pm 0.37^{\mathrm{a}}$ & $0.72 \pm 0.04^{\mathrm{a}}$ & $43.85 \pm 0.36^{\mathrm{b}}$ & $14.64 \pm 0.39^{\mathrm{b}}$ \\
DIET 4 & $2.94 \pm 0.30^{\mathrm{a}}$ & $0.70 \pm 0.04^{\mathrm{a}}$ & $73.27 \pm 0.24^{\mathrm{a}}$ & $31.19 \pm 0.45^{\mathrm{a}}$ \\
DIET 5 & $3.56 \pm 0.33^{\mathrm{a}}$ & $0.60 \pm 0.03^{\mathrm{a}}$ & $74.16 \pm 0.46^{\mathrm{a}}$ & $30.51 \pm 0.61^{\mathrm{a}}$
\end{tabular}

Mean \pm SEM (Standard Error of Mean). Diet $10 \%$, Diet $2-0.002 \%$, Diet $3-0.004 \%$, Diet 4 - 0.006\%, Diet 5 - 0.008\% taurine-supplemented diets respectively. GSH - Reduced glutathione activity, NO - Nitric oxide, CAT - Catalase, MPO - Myeloperoxidase.

Means within the same column with different superscripts are significantly different $(p<$ 0.05).

Table 5: Kidney antioxidant parameters of broiler birds fed graded level taurinesupplemented diets

\begin{tabular}{lllll}
\hline & & \multicolumn{3}{c}{ KIDNEY } \\
\hline DIETS & GSH $(\mathrm{mg} / \mathrm{dl})$ & NO $(\mathrm{ppm})$ & CAT $(\mu \mathrm{mol} / \mathrm{min})$ & MPO $(\mu \mathrm{mol} / \mathrm{min})$ \\
\hline DIET 1 & $1.82 \pm 0.11^{\mathrm{c}}$ & $0.35 \pm 0.01^{\mathrm{d}}$ & $36.29 \pm 0.39^{\mathrm{e}}$ & $1.45 \pm 0.08^{\mathrm{ab}}$ \\
DIET 2 & $1.94 \pm 0.30^{\mathrm{b}}$ & $0.38 \pm 0.01^{\mathrm{c}}$ & $53.67 \pm 0.398^{\mathrm{c}}$ & $1.23 \pm 0.04^{\mathrm{b}}$ \\
DIET 3 & $2.01 \pm 0.11^{\mathrm{ab}}$ & $0.37 \pm 0.01^{\mathrm{c}}$ & $42.71 \pm 0.48^{\mathrm{d}}$ & $1.61 \pm 0.09^{\mathrm{a}}$ \\
DIET 4 & $2.94 \pm 0.26^{\mathrm{a}}$ & $0.589 \pm 0.01^{\mathrm{a}}$ & $73.24 \pm 0.53^{\mathrm{b}}$ & $1.73 \pm 0.07^{\mathrm{a}}$ \\
DIET 5 & $3.16 \pm 0.30^{\mathrm{a}}$ & $0.45 \pm 0.01^{\mathrm{b}}$ & $75.50 \pm 0.62^{\mathrm{a}}$ & $1.79 \pm 0.03^{\mathrm{a}}$ \\
\hline
\end{tabular}

Mean \pm SEM (Standard Error of Mean). Diet $1-0 \%$, Diet $2-0.002 \%$, Diet $3-0.004 \%$, Diet $4-0.006 \%$, Diet $5-0.008 \%$ taurine-supplemented diets respectively. GSH - Reduced glutathione activity, NO - Nitric oxide, CAT - Catalase, MPO - Myeloperoxidase.

Means within the same column with different superscripts are significantly different ( $p<$ $0.05)$.

Table 6: Serum lipid profile of broiler birds fed graded level taurine-supplemented diets (mmol/L)

\begin{tabular}{lllll}
\hline DIETS & CHOLESTEROL & TRIGLYCERIDE & HDL & LDL \\
\hline DIET 1 & $760.04 \pm 4.95^{\mathrm{a}}$ & $370.60 \pm 6.32^{\mathrm{b}}$ & $145.73 \pm 0.33^{\mathrm{d}}$ & $428.24 \pm 8.92^{\mathrm{a}}$ \\
DIET 2 & $557.82 \pm 7.62^{\mathrm{c}}$ & $246.89 \pm 1.47^{\mathrm{e}}$ & $164.77 \pm 0.68^{\mathrm{b}}$ & $257.92 \pm 1.15^{\mathrm{d}}$ \\
DIET 3 & $530.96 \pm 6.31^{\mathrm{d}}$ & $273.55 \pm 0.96^{\mathrm{d}}$ & $156.17 \pm 0.72^{\mathrm{c}}$ & $259.29 \pm 8.16^{\mathrm{d}}$ \\
& & & & \\
DIET 4 & $625.19 \pm 10.37^{\mathrm{bc}}$ & $342.29 \pm 1.64^{\mathrm{c}}$ & $161.69 \pm 0.32^{\mathrm{bc}}$ & $357.79 \pm 8.14^{\mathrm{b}}$ \\
DIET 5 & $646.01 \pm 5.89^{\mathrm{b}}$ & $439.61 \pm 1.39^{\mathrm{a}}$ & $187.16 \pm 1.10^{\mathrm{a}}$ & $329.51 \pm 4.75^{\mathrm{c}}$ \\
\hline
\end{tabular}

Mean \pm SEM (Standard Error of Mean). Diet $1-0 \%$, Diet $2-0.002 \%$, Diet $3-0.004 \%$, Diet $4-0.006 \%$, Diet $5-0.008 \%$ taurine-supplemented diets respectively.

Means within the same column with different superscripts are significantly different $(p<0.05)$. 
breast weight of birds on the control diet. The drumstick weight of birds on $0.006 \%$ dietary taurine supplement was significantly higher $(p<0.05)$, this was followed by the drumstick of birds on 0.004 and $0.008 \%$ dietary taurinesupplemented diet with no significant differences $(p>0.05)$. The back weight was significantly higher $(\mathrm{p}<0.05)$ for birds on the $0.002 \%$ and neck at $0.008 \%$ dietary taurine supplements. The weight of the wing was similar $(\mathrm{p}>0.05)$ for birds placed on $0 \%$ to $0.006 \%$ taurine-supplemented diets.

Table 8 shows that the birds placed on 0.002 and $0.008 \%$ taurine-supplemented diets had significantly higher $(p<0.05)$ final weight gain at the end of the feeding trial compared with the weights of birds on other dietary level taurine supplementations (control diet inclusive). The feed to weight gain ratio also favoured $(\mathrm{p}<0.05)$ the birds on 0.002 and $0.008 \%$ taurine-supplemented diets compared with birds on other dietary taurine inclusion levels. Birds on 0, 0.004, and 0.006\% taurine-supplemented diets had similar $(p>0.05)$ feed to weight gain ratio. The weight of the various organs (Table 9) relative to the dressed body weight ratio did not reveal any concise distinctions $(p>0.05)$. Liver and kidney relative weights to dressed body weight ratios were insignificant $(p>0.05)$. Ditto for gizzard and heart $(p>0.05)$.

\section{Discussion}

The gross composition and analysed proximate compositions were within the standard as outlined by AOAC (2005). Broiler birds' feed must be balanced in energy and protein for a favourable output, as well as equally balanced in micronutrients and minerals, especially calcium and phosphorous in order to strike a balance between meat to bone ratio for good bone integrity. Taurine has been proven to maintain the bone integrity of meat-targeted poultry birds (Park et al., 2001; Yasutomi et al., 2002).

The liver and kidney total protein of broiler birds on varying taurine-supplemented diets were significantly higher $(p<0.05)$ than that of the birds on the control diet. This is an indication of the positive role of taurine in enhancing the tissue protein contents of broiler birds.
The level of the GSH in the tissue is a function of its synthesis and usage in the various oxidation/reduction reactions (Rebrin et al., 2005). Many studies had earlier reported the ability of taurine to protect the cell against oxidative damage and free radicals, hence guarding against cell death (Lakshmi and Anuradha, 2010; Das et al., 2012). Catalase and glutathione are respectively first and second levels of cell antioxidant defense mechanism, protecting against and detoxifying free radicals in the cell (Surai et al., 2019). Taurine has been proven to limit the liver consumption of GSH by mitigating the lipid peroxide reactions, a known marker that causes free radical toxicity; this will invariably favour increased amount of tissue GSH and decreased tissue toxicity (Centiner et al., 2005). Taurine and GSH have the same precursor cysteine (Rebrin et al., 2005, Dowson et al., 2002). It has also earlier been scientifically proven that TAU has the ability of increasing tissue GSH because of its ability to direct more amount of cysteine into GSH biosynthesis (Hagar, 2004 and Rebrin et al., 2005).

Generally, birds placed on 0.004 to $0.008 \%$ dietary taurine-supplemented diets possess higher and varied amounts of the studied antioxidant biomolecules both in the liver and in the kidney. The report of this research correlates with the finding of Ma et al. (2016) that reported an increase in the activity of total antioxidant capability of laying hens when their diets were supplemented with taurine. Anand et al., 2010 also reported a significant $(p<0.05)$ increase in the liver GSH level of the orally taurine administered rats at a dose of between $50 \mathrm{mg}$ to $500 \mathrm{mg}$ in $50 \%$ normal saline, but a reduction in the rats' kidney GSH level as compared with the control group. Nitric oxide is a strong peritrate of the cardiovascular system; it has a short life expectancy in the order of seconds (Thomas et al., 2006). Taurine, a biosynthetic product of methionine (a methyl donor) had earlier been proven by Faraji et al. (2019) to favour significant increase in the serum level of NO. It has also earlier been proven to help in increasing antioxidant enzyme activities as well as playing an active role in scavenging reactive oxygen species (Li, et al., 2016). Its significantly increased amount in the broiler birds' diet supplemented with taurine 
Table 7: Carcass yield (g) of broiler birds (expressed as a dressed weight percentage) fed graded level taurine-supplemented diets

\begin{tabular}{lllllll} 
DIETS & THIGH & BREAST & DRUMSTICK & BACK & NECK & WING \\
\hline Diet 1 & $10.94 \pm 0.27^{\mathrm{b}}$ & $21.10 \pm 0.71^{\mathrm{b}}$ & $09.85 \pm 0.33^{\mathrm{c}}$ & $13.98 \pm 0.43^{\mathrm{c}}$ & $5.03 \pm 0.12^{\mathrm{a}}$ & $8.88 \pm 0.19^{\mathrm{a}}$ \\
Diet 2 & $11.78 \pm 0.49^{\mathrm{ab}}$ & $24.71 \pm 0.85^{\mathrm{a}}$ & $10.03 \pm 0.20^{\mathrm{c}}$ & $17.48 \pm 1.14^{\mathrm{a}}$ & $4.21 \pm 0.13^{\mathrm{b}}$ & $8.80 \pm 0.36^{\mathrm{a}}$ \\
Diet 3 & $12.63 \pm 0.39^{\mathrm{a}}$ & $23.83 \pm 0.68^{\mathrm{a}}$ & $10.49 \pm 0.26^{\mathrm{b}}$ & $13.76 \pm 0.50^{\mathrm{c}}$ & $4.50 \pm 0.16^{\mathrm{ab}}$ & $8.74 \pm 0.31^{\mathrm{a}}$ \\
Diet 4 & $10.81 \pm 0.29^{\mathrm{b}}$ & $23.99 \pm 0.75^{\mathrm{a}}$ & $11.49 \pm 0.47^{\mathrm{a}}$ & $14.34 \pm 0.42^{\mathrm{b}}$ & $4.59 \pm 0.22^{\mathrm{ab}}$ & $9.14 \pm 0.44^{\mathrm{a}}$ \\
Diet 5 & $11.43 \pm 0.33^{\mathrm{ab}}$ & $25.20 \pm 0.56^{\mathrm{a}}$ & $10.48 \pm 0.19^{\mathrm{b}}$ & $14.21 \pm 0.57^{\mathrm{b}}$ & $4.84 \pm 0.21^{\mathrm{a}}$ & $8.49 \pm 0.35^{\mathrm{b}}$ \\
\hline
\end{tabular}

Mean \pm SEM (Standard Error of Mean). Diet $1-0 \%$, Diet $2-0.002 \%$, Diet $3-0.004 \%$, Diet $4-0.006 \%$, Diet $5-0.008 \%$ taurine-supplemented diets respectively.

Means within the same column with different superscripts are significantly different $(p<0.05)$.

Table 8: Weight gain (g) and feed to weight gain ratio of broiler birds fed graded level taurinesupplemented diets

\begin{tabular}{llllll}
\hline Parameters $(\mathrm{g})$ & DIET 1 & DIETS 2 & DIETS 3 & DIETS 4 & DIETS 5 \\
\hline Final weight gain/bird/7 weeks & $1856.25^{\mathrm{b}}$ & $1988.50^{\mathrm{a}}$ & $1809.00^{\mathrm{d}}$ & $1826.75^{\mathrm{c}}$ & $1996.00^{\mathrm{a}}$ \\
Total feed intake/bird/7 weeks & $3208.78^{\mathrm{c}}$ & $3270.09^{\mathrm{b}}$ & $3215.14^{\mathrm{c}}$ & $3238.54^{\mathrm{a}}$ & $3238.88^{\mathrm{a}}$ \\
Feed/weight gain ratio & $1.73^{\mathrm{a}}$ & $1.64^{\mathrm{b}}$ & $1.77^{\mathrm{a}}$ & $1.77^{\mathrm{a}}$ & $1.62^{\mathrm{b}}$ \\
SEM & 0.13 & 0.12 & 0.13 & 0.13 & 0.12
\end{tabular}

Mean \pm SEM (Standard Error of Mean). Diet $1-0 \%$, Diet $2-0.002 \%$, Diet $3-0.004 \%$, Diet $4-0.006 \%$, Diet $5-0.008 \%$ taurine-supplemented diets respectively.

Means within the same column with different superscripts are significantly different $(p<0.05)$.

Table 9: Organs/dressed body weight ratio (\%) of broiler birds fed graded level taurinesupplemented diets

\begin{tabular}{lllll}
\hline DIETS & Liver & Kidney & Heart & Gizzard \\
\hline DIET 1 & $1.86 \pm 0.06^{\mathrm{a}}$ & $0.49 \pm 0.03^{\mathrm{a}}$ & $0.55 \pm 0.02^{\mathrm{a}}$ & $2.19 \pm 0.10^{\mathrm{a}}$ \\
DIET 2 & $1.88 \pm 0.07^{\mathrm{a}}$ & $0.50 \pm 0.02^{\mathrm{a}}$ & $0.51 \pm 0.03^{\mathrm{a}}$ & $2.21 \pm 0.11^{\mathrm{a}}$ \\
DIET 3 & $1.90 \pm 0.06^{\mathrm{a}}$ & $0.51 \pm 0.03^{\mathrm{a}}$ & $0.58 \pm 0.01^{\mathrm{a}}$ & $2.25 \pm 0.10^{\mathrm{a}}$ \\
DIET 4 & $1.94 \pm 0.07^{\mathrm{a}}$ & $0.53 \pm 0.03^{\mathrm{a}}$ & $0.55 \pm 0.02^{\mathrm{a}}$ & $2.15 \pm 0.07^{\mathrm{a}}$ \\
DIET 5 & $1.95 \pm 0.08^{\mathrm{a}}$ & $0.53 \pm 0.02^{\mathrm{a}}$ & $0.58 \pm 0.01^{\mathrm{a}}$ & $1.95 \pm 0.10^{\mathrm{b}}$
\end{tabular}

Mean \pm SEM (Standard Error of Mean). Diet $1-0 \%$, Diet $2-0.002 \%$, Diet $3-0.004 \%$, Diet $4-0.006 \%$, Diet $5-0.008 \%$ taurine-supplemented diets respectively.

Means within the same column with different superscripts are significantly different $(p<0.05)$. 
in this research proves its antioxidant ability in neutralizing free radicals in broiler birds.

Myeloperoxidase (MPO) is intimately involved in cellular homeostasis; it is an important factor in the initiation and progression of various inflammatory diseases (Vtjayakumar et al., 2011). The main cellular source of MPO is the neutrophil (Klebanoff, 2005). The complete MPO system consists of MPO, $\mathrm{H}_{2} \mathrm{O}_{2}$, and an oxidizable factor. The degeneration of $\mathrm{MPO}-\mathrm{H}_{2} \mathrm{O}_{2}$ normally generates $\mathrm{HOCl}$, hydroxyl radicals ( $\mathrm{HO} \cdot)$, singlet oxygen $\left({ }^{1} \mathrm{O}_{2}\right)$, and ozone $\left(\mathrm{O}_{3}\right)$ (Klebanoff, 2005, Davies et al., 2008). Taurine sulphonic acid is present in abundance in the cytoplasm of neutrophils. It will react with $\mathrm{HOCl}$ to produce taurine chloramine (TauCl) that is less toxic (Learn et al., 1990), hence it is expected to protect the neutrophils from the more toxic effect of $\mathrm{HOCl}$. $\mathrm{TauCl}$ synthesized and released from the activated neutrophils may halt the excessive production of $\mathrm{O}_{2}^{-}$, hence protecting neutrophils from the selfimposed cytotoxicity of reactive oxygen species and oxidative stress (Ogino et al., 1997; Chaekyun and Young-Nam, 2013). The higher amount of MPO in the form of $\mathrm{TauCl}$ in the liver and kidney of the birds fed varying taurine-supplementeddiets, especially at between 0.004 and $0.008 \%$, is an indication of the ability of the tissues to guard against oxidative stress and inhibit severe inflammation.

Nutritionally, lipid profile is an indication of the quality of the fatty acids in the experimental diet. It gives more information, especially as it has to do with high and low density profiles of the sample. An experimental sample that possesses higher high density lipoprotein would indicate normal lipid metabolism and the proper functionality of the heart (Ogunbode et al., 2018). The report of these findings is in line with the work of Alzawqari et al. (2016) and Zeng et al. (2012) that reported a higher HDL and lower LDL for birds placed on 0.25 to $0.5 \%$ taurine-supplemented diets. Ghasemi and Nari (2019) also reported that the supplementation of betaine (Bet- another derived or modified amino acid) supplementation in broiler birds diet favoured increased level of triglycerides. Matsushima et al. (2003) and Militante and Lombardini (2004) had earlier reported that a diet supplemented with taurine is capable of reducing serum and liver cholesterol.

Carcass characteristics denote the effect of experimental diet on birds' cut parts like the breast, the thigh and the drumstick as compared with same carcass of the birds on the control diet. The observed outstanding carcass weight of birds on varying taurine-supplemented diets in this research is in line with the findings of Huang et al. (2014), who reported a higher amount of taurine in the cut parts (breast and thigh) of broiler birds when there feeds were supplemented with taurine at a level of between 4 and $8 \mathrm{~g} / \mathrm{kg}$ diets. Satsu et al. (2002) and Sved et al. (2007) had also reported an increased muscle taurine content of rats when their diets were supplemented with taurine. The outcome of this research on the other hand negates the findings of Alzawqari et al. (2016) who reported a nonsignificant effect of taurine supplementation on the carcass output of broiler chickens.

Weight gain, mostly the final weight gain of experimental birds is usually a reflection of the effect of experimental feed over a period of time in comparison with the weight of birds on the control diet. The feed to weight gain ratio on the other hand has to do with the rate at which the birds are able to convert the experimental feed served to meat. It had earlier been proven that taurine supplementation at a rate of between 0.5 and $8.0 \mathrm{~g} / \mathrm{kg}$ in broiler diet had a positive effect on the feed conversion ratio mostly at the starter phase (Blair et al., 1991; Tufft and Jensen, 1992). The increased final weight and favourable feed conversion ratio of birds on 0.002 and $0.008 \%$ in this research supports the finding of Shim et al. (2006) and Belal et al. (2018) that reported a higher weight gain for broiler chickens subjected to heat stress but with diets supplemented with taurine than birds subjected to heat stress only. Faraji et al. (2019) had also reported an attenuation effect of Tau on the final weight and feed conversion ratio of broiler birds earlier fed with guanidinoacetic acid (GAA). Betaine, just like taurine has also been proven to favour increased weight gain, feed intake and feed to weight gain ratio of broiler birds under heat stress condition (Ghasemi and Nari, 2019). In contrast, our research findings is not in agreement with the findings of Tufft and Jensen (1992) that reported a non- 
significant difference in the weight gain and feed efficiency of broilers fed $0.8 \%$ dietary taurinesupplemented-diet. Campbell and Classen (1989) also reported a negative feed to weight gain ratio when male broiler birds were fed 0 to $0.2 \%$ taurinesupplemented diets. Blair et al. (1991) equally reported a negative feedback when broiler birds were fed taurine-supplemented-diets varying between 0.025 and $0.5 \%$. Differences in results might be as a result of quantities of taurine used, ration formulation method, the genetic make-up of the broiler birds, or due to some other cogent reasons. Organ to body weight ratio is the relative percentage weight of the organs to dressed weight of birds. It is mostly used as an index of toxicity or otherwise in the organs of experimental birds as compared to those of the birds on the control diet. Non-significant weight of the studied organs of birds on varying Tau supplemented diets in comparison with the weight of same organs for birds on the control diets is an indication of the relative safety of Tau in birds' diet, hence its safety for the final consumer of meat of the birds.

\section{Conclusion}

Taurine-supplemented diets between 0.002 and $0.008 \%$ favoured birds' antioxidant defense mechanisms, had no deleterious effect on lipid profile, and equally improved the performance characteristics of broiler birds. Consuming taurinerich broiler chicken meat by humans will also help in alleviating several health challenges like obesity and cardiovascular dysfunction, because of its positive role on lipid profiles.

\section{References}

Abplanalp, W., Haberzettl, P., Bhatnagar, A., Conklin, D.J. \& O'Toole, T.E. (2019). Carnosine supplementation mitigates the deleterious effects of particulate matter exposure in mice. Journal of the American Heart Association, 8:e013041.

Ajiboye, T.A., Adeleye, A.O., Salau, A.K., Ojewuyi, O.B., Adigun, N.S., Sabiu, S. \& Sumonu, T.O. (2014). Phenolic extract of Parkia biglobosa fruit pulp stalls aflatoxin B1mediated oxidative rout in the liver of male rats.
Brazilian Journal of Pharmacognosy, 24, 668676.

Alzawqari, M.H., Al-Baadani, H.H., Alhidary, I.B., Al-Owaimer, A.N. \& Abudabos, A.M. (2016). Effect of taurine and bile acid supplementation and their interaction on performance, serum components, ileal viscosity and carcass characteristics of broiler chickens. South African Journal of Animal Science, 46 (4), 448-457.

Anand, P., Rajakumar, D., Felix, A.J.W. \& Balasubramanian T. (2010). Effects of oral administration of antioxidant taurine on haematological parameters in wistar rats. Pakistan Journal of Biological Sciences, 13, 85 $-793$.

Avgerinos, K.I., Spyrou, N., Bougioukas, K.I. \& Kapogiannis D. (2018). Effects of creatine supplementation on cognitive function of healthy individuals. Experimental Gerontology, 108, 166-173.

Begley, M., Gahan, C.G. \& Hill, C. (2005). The interaction between bacteria and bile. FEMS Microbiology Reviews, 29, 625-651.

Belal, S.A, Kang, D.R., Cho, E.S.R., Park, G.H. \& Shim, K.S. (2018). Taurine reduces heat stress by regulating the expression of heat shock proteins in broilers exposed to chronic heat. Brazilian Journal of Poultry Science, 20 (3), 479-486.

Blair, R., Jacob, J.P. \& Gardiner, E.E. (1991). Lack of an effect of taurine supplementation on the incidence of sudden death syndrome in male broiler chicks. Poultry Science, 70 (3), 554-560. doi:10.3382/ps.0700554.

Bradford, M.M. (1976). A rapid and sensitive method for the quantitation of microgram quantities of protein utilizing the principle of protein-dye binding. Analytical Biochemistry, 72(1), 248-54.

Campbell, G. \& Classen, H. (1989). Effect of dietary taurine supplementation on sudden death syndrome in broiler chickens. Canadian Journal of Animal Science, 69, 509-512. doi:10.4141/cjas89-060

Cetiner, M., Sener, G., Sehirli, A.O., EkşioğluDemiralp, E., Ercan, F., Sirvanci, S., Gedik, N., Akpulat, S., Tecimer, T. \& Yeğen, B.C. (2005). Taurine protects against methotrexate - induced 
toxicity and inhibits leukocyte death. Toxicology and Applied Pharmacology, 209(1), $39-50$.

Chaekyun, K. \& Young-Nam C. (2013). Taurine chloramine produced from taurine under inflammation provides anti-inflammatory and cytoprotective effects. Amino Acids, 46(1), 89100. doi: 10.1007/s00726-013-1545-6.

Das, J., Roy, A. \& Sil, P.C. (2012). Mechanism of the protective action of taurine in toxin and drug induced organ pathophysiology and diabetic complications: a review. Food and Functions Journals, 3(12), 1251-1264. doi: http://dx.doi.org/10.1039/c2fo30117b.

Davies, M.J., Hawkins, C.L., Pattison, D.I. \& Rees, M.D. (2008). Mammalian heme peroxidases: from molecular mechanisms to health implications. Antioxidant Redox Signal, 10, 1199-1234.

Dowson, R., Biasetti, M., Messina, S. \& Dominy, J. (2002). The cytoprotective role of taurine in exercise-induced muscle injury. Amino Acids, 22: $309-324$.

Faraji, M., Karimi, D.S, Zamiani Moghadam, A.K., Ahmadipour, B. \& Khajali, F. (2019). Combined effects of guanidinoacetic acid, coenzyme Q10 and taurine on growth performance, gene expression and ascites mortality in broiler chickens. Journal of Animal Physiology and Animal Nutrition.103, 162-169. https://doi.org/10.1111/jpn.13020.

Folch, J., lees, M. \& Stanley, G.H. S. (1957).

A simple method for the isolation and purification of total lipides from animal tissues. Journal of Biological Chemistry, 226 (1), 497-509.

Ghasemi, A. H. \& Nari, N. (2019). Effect of supplementary betaine on growth performance, blood biochemical profile, and immune response in heat-stressed broilers fed different dietary protein levels. Journal of Applied Poultry Research. https://doi.org/10.1016/j.japr.2019.11.004.

Green, T.R., Fellman, J.H., Eicher, A. L. \& Pratt, K. L. (1991). Antioxidant role and subcellular localization of hypotaurine and taurine in human neutrophils. Biochimica et Biophysica Acta 1073:91-97. http://dx.doi.org/10.1007/s00726-009-0293-0.
Hagar, H.H. (2004). The protective effect of taurine against cyclosporine A-induced oxidative stress and hepatotoxicity in rats. Toxicology Letters, 151, 335343.

Huang, C., Guo, Y. \& Yuan, J. (2014a). Dietary taurine impairs intestinal growth and mucosal structure of broiler chickens by increasing toxic bile acid concentrations in the intestine. Poultry. Science, 93 (6), 1475-1483.

Huang, C.X., Wang, B., Min, Z. \& Yuan, J. (2014): Dietary inclusion level and time effects of taurine on broiler performance, meat quality, oxidative status and muscle taurine content, British Poultry Science, 5(5), 598-604.

Klebanoff, S.J. (2005). Myeloperoxidase: friend and foe. Journal of Leukocyte Biology, 77 (5), 598-625.

Lakshmi, D.S. \& Anuradha, C. (2010). mitochondrial damage, cytotoxicity and apoptosis in iron-potentiated alcoholic liver fibrosis: amelioration by taurine. Amino Acids, 38 (3), 869-879.

Learn, D.B., Fried, V.A. \& Thomas, E.L. (1990). Taurine and hypotaurine content of human leukocytes. Journal of Leukocyte Biology, 48 (2), 174-182.

Li, M., Lai, H., Li, Q., Gong, S.Y.\& Wang, R.X. (2016). Effects of dietary taurine on growth, immunity and hyperammonemia in juvenile yellow catfish pelteobagrus fulvidraco fed allplant protein diets. Aquaculture, 450, 349-355.

Ma, Z., Gao, Y., Ma, H., Zheng, L., Dai B., Miao, J. \& Zhang, Y. (2016). Effects of taurine and housing density on renal function in laying hens. Journal of Zhejiang University-Science B (Biomediine \& Biotechnology), 17(12), 952964.

Matsushima, Y., Sekine, T., Kondo, Y., Sakurai, T., Kameo, K., Tachibana, M. \& Murakami, S. (2003). Effects of taurine on serum cholesterol levels and development of atherosclerosis in spontaneously hyperlipidaemic mice. Clinical and Experimental Pharmacology and Physiology, 30, 295-299.

Militante, J.D. \& Lombardini, J. B. (2004). Dietary taurine supplementation: hypolipidemic and 
antiatherogenic effects. Nutrition. Research, 24, 787-801.

Ogino, T., Kobuchi, H., Sen, C.K., Roy, S., Packer, L. \& Maguire, J.J. (1997). Monochloramine inhibits phorbol ester-inducible neutrophil respiratory burst activation and $\mathrm{T}$ cell interleukin-2 receptor expression by inhibiting inducible protein kinase C activity. Journal of Biological Chemistry, 272, 2624726252.

Ogunbode, S M., Iyayi E. A, Owoade A. A \& Okanlawon A. A., (2013). "Effect of Low Protein-Methionine-and-Lysine-Supplemented Diets on Performance, Immune Response and Carcass Characteristics of Broilers" Bulletin of Animal Health and Production in Africa, 61, 369-382.

Ogunbode, S. M., Salau A. K., Azeez L.A,, Osineye, S. O., Olaogun, O.O, Adebisi, J. O., Akinlade H. O. \& Isa F. O. (2018). Carcass characteristics and selected tissue enzymes activities of birds injected with cocoa pod husk extract mediated - silver nanoparticles (CPHEAgNPs) at day old. Science Focus, 23(2), 81-90.

Park, S., Kim, H. \& Kim, S.J. (2001). Stimulation of ERK2 by taurine with enhanced alkaline phosphatase activity and collagen synthesis in osteoblast-like UMR-106 cells. Biochemical Pharmacoogyl._62, 1107-1111.

Rebrin, I., Zicker, S., Wedekind, K.J., PaetauRobinson, I., Packer, L. \& Sohal, R.S. (2005). Effect of antioxidant-enriched diets on glutathione redox status in tissue homogenates and mitochondria of the senescence-accelerated mouse, Free Radicals. Biology and Medicine, 39: 549 - 557.

Reshetnyak, V.I. (2013). Physiological and molecular biochemical mechanisms of bile formation. World Journal of Gastroenterology. 19, 7341-7360.

Satsu, H., Kobayashi, Y., Yokoyama, T., Terasawa, E. \& Shimizu, M. (2002) Effect of dietary sulfur amino acids on the taurine content of rat tissues. Amino Acids, 23, 447-452. doi:10.1007/s00726-002-0214-y.

Shim, K.S., Hwang, K.T., Son, M.W. \& Park, G.H. (2006). Lipid metabolism and peroxidation in broiler chickens under chronic heat stress.
Asian-Australasian Journal of Animal Science, 19,1206-1211.

Surai, P. F., Kochis, I.I. \& Fisinin, V.I. (2017). Antioxidant systems in poultry biology: Nutritional modulation of vitagenes. European Poultry Science Journal, 81, 2017 doi: 10.1399/eps.2017.214.

Surai, P. F., Kochish, I. I., Fisinin, V. I. \& Kidd, M. T. (2019). Antioxidant Defence Systems and Oxidative Stress in Poultry Biology: An Update. Antioxidants 2019, 8, 235. doi:10.3390/antiox8070235.

Sved, D., Godsey, J., Ledyard, S., Mahoney, A., Stetson, P., Ho, S., Myers, N., Resnis, P. \& Renwick, A. (2007). Absorption, tissue distribution, metabolism and elimination of taurine given orally to rats. Amino Acids, 32, 459-466. doi:10.1007/s00726-007-0494-3.

Thomas, S. R., Schulz, E. \& Keanney, J. F. (2006). Hydrogen peroxide restrains endothelium derived nitric oxide bioactivity-Role for irondependent oxidative stress. Free Radical Biology and Medicine; 41, 681-688.

Tomaz, H.A., Sabrina, S., Eliver, E.G., Noemi, N.T., Maria, R.R., Sandro, R.A., Renato, A. M., Momtchilo, R., Ana, C. \& Renata C.A. (2013). Intracellular localization of myeloperoxidase in murine peritoneal B-lymphocytes and macrophages. Cellular Immunology, 28 (1), 27-30.

Tufft, L.S. \& Jensen, L.S. (1992) Influence of dietary taurine on performance and fat retention in broilers and turkey poults fed varying levels of fat. Poultry Science, 71, 880-885. doi:10.3382/ps.0710880.

Vtjayakumar, A., Yakar, S. \& Leroth, D. (2011). The intricate role of growth hormone in metabolism. Frontiers in Endocrinology, (2)32. Wu, Z.L., Hou, Y.Q., Dai, Z.L. Hu, C.A. \& Wu, G.Y. (2019). Metabolism, nutrition and redox signaling of hydroxyproline. Antioxidant Redox Signal, 30, 674-682.

Yasutomi, C., Nakamuta, H., Fujita, T., Takenaga, T. \& Koida, M. (2002): Anti-osteopenic effect of taurine: possible involvement of activated MEK-ERK-Cbfa1 signaling Nippon Yakurigaku Zasshi-Japaneese Journal of Pharmacology 120, 114-115. 
Zeng, D.S., Gao, Z.H., Huang, X.L., Zhao, J.H., Huang, G.Q. \& Duo, L. (2012). Effect of taurine on lipid metabolism of broilers. Journal of Applied Animal Research 40, 86-89. 